$\begin{gathered}\text { Науковий вісник НлтУ України } \\ \text { Scientific Bulletin of UNFU } \\ \text { https://nv.nltu.edu.ua }\end{gathered}$
$\begin{array}{r}\text { https://doi.org/10.15421/40280924 (i) ISSN 1994-7836 (print) } \\ \text { ISSN 2519-2477 (online) } \\ \text { Article received 16.10.2018 p. } \\ \text { Article accepted 25.10.2018 p. } \\ \text { Удк 368:338 }\end{array}$
$\begin{array}{r}\text { N. M. Tsebenko } \\ \text { n.tsebenko@gmail.com }\end{array}$

Н. М. Цебенко

Дрогобицький державний педагогічний університет ім. Івана Франка, м. Дрогобич, Україна

\title{
ВПЛИВ РЕСУРСІВ СТРАХОВОГО РИНКУ НА МОДЕРНІЗАЦІЮ ВИРОБНИЧОЇ ІНФРАСТРУКТУРИ УКРАЇНСЬКОЇ ЕКОНОМІКИ
}

\begin{abstract}
Досліджено основні тенденції розвитку страхового ринку України. Охарактеризовано страховий ринок як стратегічно важливий та перспективний сегмент економіки і джерело внутрішніх довгострокових інвестицій в національну економіку, зокрема в модернізацію виробничої інфраструктури. Визначено сутність інвестиційної діяльності страхових компаній у сфері виробничої інфраструктури. Страхові компанії можна віднести до установ, яким притаманна можливість продукувати насамперед довгострокові інвестиційні ресурси, дефіцит яких спостерігається в українській економіці. Простежено зростання інвестиційних ринків України, що значною мірою може бути забезпечено завдяки ефективному використанню страхових ресурсів вітчизняних страхових компаній. Вказано, що інвестиційна функція страхового ринку реалізується через розміщення тимчасово вільних засобів у цінні папери, депозити банків, нерухомість тощо. Виявлено основні джерела інвестиційної діяльності страхових компаній - власні кошти (статутний фонд, резервний фонд, прибуток, цільове фінансування і надходження) та залучені кошти (поточне надходження страхових премій, резерви страхових внесків та відшкодувань, фонд запобіжних заходів). Запропоновано напрями вдосконалення державного регулювання інвестиційної діяльності страхових компаній: вдосконалення законодавчої бази та ринку капіталів, щоб забезпечити ефективне функціонування страхових компаній у сфері інвестування.
\end{abstract}

Ключові слова: виробнича інфраструктура; інвестиції; страхова компанія; страховий ринок.

Вступ. Модернізація економіки України та ії прагнення до євроінтеграції створюють умови для функціонування підприємств у ринковому середовищі з урахуванням усіх чинників макрооточення. Страховий ринок є стратегічно важливим і перспективним сегментом економіки і $є$ джерелом внутрішніх довгострокових інвестицій в національну економіку, зокрема в модернізацію виробничої інфраструктури. Страхування $є$ основою суспільного розвитку, його збалансованості та стабільності.

Актуальність цієї теми полягає в тому, що інвестиції та інвестиційна діяльність завжди перебували в центрі уваги економічної науки. Насамперед це пояснюють тим, що інвестиції є джерелом розвитку економіки, а інвестиційна діяльність впливає на фундаментальні основи господарської діяльності, економічні та соціальні перетворення і розвиток суспільства загалом.

Важливими учасниками інвестиційного ринку $є$ й страхові компанії, які, з одного боку, належать до потужних інституційних інвесторів, а з іншого - пропонують інвесторам страховий захист їхніх вкладень від можливих втрат, що виникають внаслідок несприятливих та непередбачуваних змін політичної ситуації, кон'юнктури ринку, і тим впливають на інвестиційний клімат у країні.

Аналіз останніх досліджень і публікацій. Аналіз діяльності страхових компаній дає змогу об'єктивно визначити стан українського страхового ринку, з'ясува- ти його місце в розвитку фінансового ринку загалом та ідентифікувати вклад страхового ринку в модернізацію виробничої інфраструктури.

Проблематика функціонування страхового ринку, через його важливість для розвитку національної економіки, завжди була в центрі уваги дослідників, зокрема: Віктора Базилевича, Віри Братюк, Тетяни Овчаренко, Олени Сови (Bazylevych, 1998; Bratiuk, 2016; Ovcharenko, 2011; Sova, 2015) та ін. Проте ці проблеми на сьогодні залишаються надзвичайно актуальними і потребують подальшого дослідження.

Мета роботи - дослідити роль фінансових ресурсів страхових компаній у модернізації галузей виробничої інфраструктури української економіки.

Викладення основного матеріалу. Страхування це потужна ланка фінансово-кредитної системи, яку вважають однією з найбільш інтегрованих форм фінансової діяльності. Страховий ринок $є$ важливою складовою розвитку національної економіки будь-якої країни. Держава завжди зацікавлена в розвитку фінансових ринків загалом і ринку фінансових послуг зокрема, на якому одними з основних учасників є страхові компанії.

Саме вони мають змогу перетворювати тимчасово вільні кошти фізичних та юридичних осіб в інвестиційні ресурси, які необхідні економіці, що розвивається. Серед інших типів фінансових посередників, страхові компанії можна віднести до установ, яким притаманна можливість продукувати насамперед довгострокові ін-

Інформація про авторів:

Цебенко Наталія Михайлівна, аспірант. Email: n.tsebenko@gmail.com

Цитування за ДСтУ: Цебенко Н. М. Вплив ресурсів страхового ринку на модернізацію виробничої інфраструктури Української економіки. Науковий вісник НлтУ України. Серія Економічна. 2018, т. 28, № 9. С. 126-130

Citation APA: Tsebenko, N. M. (2018). Market resources insurance influence on Ukrainian economy industrial infrastructure modernization. Scientific Bulletin of UNFU, 28(9), 126-130. https://doi.org/10.15421/40280924 
вестиційні ресурси, дефіцит яких спостерігають в українській економіці.

Головними завданнями розвитку страхування є підвищення конкурентоспроможності, рівня інвестиційної привабливості страхових компаній, розвиток сучасної інфраструктури страхового ринку, створення єдиних баз даних страхових компаній (Sova, 2015).

Інвестиційна діяльність страхових компаній $є$ досить важливою складовою соціально-економічного розвитку суспільства. У розвинених країнах світу страхові компанії $є$ не лише тими підприємницькими структурами, які пропонують страховий захист, але й важливими інвестиційними інститутами (Ovcharenko, 2011). В Україні страхові компанії пропонують не тільки страховий захист майнових інтересів фізичних та юридичних осіб, але й $є$ учасниками інвестиційного ринку країни.

У розвинених країнах велика частина інвестиційних вкладень $є$ довгостроковою і здійснюється за рахунок коштів компаній зі страхування життя, тоді як в Україні основна частина коштів представлена короткостроковими активами. Українські страхові компанії тільки починають розвивати інвестиційну діяльність. Страховикам сьогодні необхідно створити передумови для подальшого перетворення страхових компаній у сильних інституційних інвесторів, яким би довіряли громадяни.

Основним джерелом одержання прибутку для страхової організації більшості цивілізованих країн $є$ не збір страхових платежів, а інвестиційна діяльність, кошти від якої спрямовуються зазвичай на фінансування страхових операцій, на дотації збитковим видам страхування, розроблення нових продуктів, підготовку кадрів тощо.

На думку Віри Братюк, "страхові компанії виступають у двох якостях. 3 одного боку в процесі здійснення своєї основної (операційної) діяльності страхові компанії страхують економічні інтереси суб'єктів господарювання від імовірних ризиків і цим самим стимулюють інвестиційну активність, 3 іншого - виступають безпосередніми інвесторами" (Bratiuk, 2016).

До напрямів інвестування галузей економіки за рахунок коштів страхових резервів Кабінет Міністрів України зарахував: розроблення та впровадження високотехнологічного устаткування й іншої інноваційної продукції; розвиток інфраструктури туризму; добування корисних копалин і перероблення відходів гірничо-металургійного виробництва; будівництво житла та розвиток ринку іпотечного кредитування; розвиток транспортної інфраструктури; розвиток сектору зв'язку та телекомунікацій (Resolution, 2002).

Зростання інвестиційних ринків України значною мірою може бути забезпечено завдяки ефективному використанню страхових ресурсів вітчизняних страхових компаній. Сьогодні цей напрям діяльності страховиків в Україні залишається недостатньо розвиненим і використаним. Однак у перспективі його реалізація здатна забезпечити піднесення національної економіки. Структуру активів страхових компаній відображено в табл. 1.

У сучасних умовах важливого значення набуває вирішення проблем економічного, організаційно-правового, функціонального, інформаційно-аналітичного, кадрового та соціально-психологічного характеру, що стримують як розвиток вітчизняного страхового ринку, так і здійснення страховими компаніями ефективної інвестиційної діяльності. У цьому контексті особливої ак- туальності набуває система заходів щодо активізації та вдосконалення інвестиційної діяльності страховиків.

Незважаючи на те, що метою страхової діяльності є надання послуг, які мають велике соціальне значення, а метою інвестиційної діяльності є одержання прибутку, вони органічно пов'язані між собою. 3 одного боку, джерелом фінансування інвестиційної діяльності є страховий фонд, з іншого - прибуток від інвестиційної діяльності може бути спрямований на фінансування страхових операцій: вживання превентивних заходів, підготовку кадрів, опрацювання нових видів страхування тощо.

Страхові компанії посідають особливе місце в забезпеченні інвестиційного процесу. 3 одного боку, вони самі здатні виконувати функції інституціональних інвесторів, мобілізуючи значну частину фінансових ресурсів юридичних і фізичних осіб та спрямовуючи їх у різні види інвестицій. 3 іншого боку, за допомоги страхування можна забезпечити стимулювання інвестиційної діяльності вітчизняних та іноземних власників капіталу через здійснення страхових операцій за видами страхування, що гарантують інвесторам повернення вкладених коштів, а в багатьох випадках і відшкодування не отриманого доходу за настання різних несприятливих подій, що призвели до фінансових втрат.

Більшість страхових компаній не має ретельно розробленої інвестиційної стратегії та вкладає кошти у фінансові інструменти афілійованих (дочірних) структур чи в банківські депозити. Із розвитком страхового ринку в частині його реального сегменту потреба в безпечному та ефективному розміщенні коштів страхових компаній буде зростати.

Вирішити це завдання можна лише за умови наявності відповідного інформаційного та кадрового забезпечення. Страхові компанії, надаючи послуги з покриття ризиків, самі відчувають потребу у професійних управлінцях передусім на фондовому ринку. Нині 70,6 \% страховиків наголосили, що під час організації інвестиційної діяльності користуються послугами штатних фахівців; по 23,5\% - компаній з управління активами та позаштатних консультантів; і лише 5,9\%-дочірньої інвестиційної компанії.

Ринок страхових послуг є другим за рівнем капіталізації серед інших небанківських фінансових ринків. Загальна кількість страхових компаній станом на 31.12.2017 p. становила 294, у тому числі: CK "life"1-33 компанії, CK "non-life" - 271 компанія (станом на 31.12.2016 p. - 310 компаній, у тому числі: СК "life" - 39 компаній, CK "non-life" - 271 компанія). Кількість страхових компаній має тенденцію до зменшення, так за 2017 р., порівняно з 2016 р., кількість компаній зменшилася на 16 СК, порівняно з 2015 р., - зменшилася на 67 СК (Results, 2017).

Страхові компанії є одними з основних видів спеціальних небанківських кредитно-фінансових установ. Інвестиційна функція страхового ринку реалізується через розміщення тимчасово вільних засобів у цінні папери, депозити банків, нерухомість тощо (Sobol', 2012). Вона передбачає вкладення тимчасово вільних коштів страховика в об'єкти підприємницької та інших видів діяльності 3 метою отримання прибутку. Однією із форм залучення коштів страховими компаніями $є$ продаж страхових полісів. Головна стаття активів страхових компаній - облігації промислових компаній, акції, державні цінні папери. 
Інвестиції в економіку України за напрямами, визначеними Кабінетом Міністрів України, на 31.12.2017 р. становили 99,0 млн грн (0,3\%) від активів страхових компаній (57 381,0 млн грн), зокрема: розроблення та впровадження високотехнологічного устаткування, іншої інноваційної продукції, ресурсо- та енергозберігаючих технологій - 3,0 млн грн $(0,008 \%)$; розвиток ін- фраструктури туризму - 30,7 млн грн $(0,1 \%)$; добування корисних копалин - 0,0 млн грн $(0,0 \%)$; перероблення відходів гірничо-металургійного виробництва 0,0 млн грн $(0,0 \%)$; будівництво житла - 5,8 млн грн $(0,02 \%)$; розвиток транспортної інфраструктури, зокрема будівництво та реконструкція автомобільних доріг 53,2 млн грн (0,1\%) (Results, 2017).

Табл. 1. Інвестування страховим ринком галузей економіки України за напрямами, визначеними Кабінетом Міністрів України

\begin{tabular}{|c|c|c|c|c|}
\hline \multirow{3}{*}{ Сфера інвестування } & \multicolumn{4}{|c|}{ Актив станом на дату: } \\
\hline & \multicolumn{2}{|c|}{ мЛн грн } & \multicolumn{2}{|c|}{$\%$} \\
\hline & 31.12 .2016 & 31.12 .2017 & 31.12 .2016 & 31.12 .2017 \\
\hline $\begin{array}{l}\text { Інвестиції в економіку України за напрямами, визначеними Кабінетом } \\
\text { Міністрів України }\end{array}$ & 31,9 & 99,0 & 0,1 & 0,3 \\
\hline $\begin{array}{l}\text { Розроблення та впровадження високотехнологічного устаткування, ін- } \\
\text { шої інноваційної продукції, ресурсо- та енергозберігаючих технологій }\end{array}$ & 2,1 & 3,0 & 0,006 & 0,008 \\
\hline Розвиток інфраструктури туризму & 29,8 & 30,7 & 0,1 & 0,1 \\
\hline Добування корисних копалин & 0,0 & 0,0 & 0,0 & 0,0 \\
\hline Перероблення відходів гірничо-металургійного виробництва & 0,0 & 0,0 & 0,0 & 0,0 \\
\hline Будівництво житла & 0,0 & 5,8 & 0,0 & 0,02 \\
\hline $\begin{array}{l}\text { Розвиток транспортної інфраструктури, зокрема будівництво та ре- } \\
\text { конструкція автомобільних доріг }\end{array}$ & 0,0 & 53,2 & 0,0 & 0,1 \\
\hline Розвиток сектору зв'язку та телекомунікацій & 0,0 & 6,3 & 0,0 & 0,02 \\
\hline $\begin{array}{l}\text { Розвиток ринку іпотечного кредитування шляхом придбання цінних па- } \\
\text { перів, емітованих Державною іпотечною установою }\end{array}$ & 0,0 & 0,0 & 0,0 & 0,0 \\
\hline
\end{tabular}

Складено автором на основі (Results, 2017).

Табл. 2. Динаміка страхових резервів та активів страховиків, млн грн (2012-2017 рр.)

\begin{tabular}{|c|c|c|c|c|c|c|}
\hline \multirow{2}{*}{ Показник } & \multicolumn{6}{|c|}{ Роки спостереження: } \\
\hline & 2012 & 2013 & 2014 & 2015 & 2016 & 2017 \\
\hline Обсяг сформованих страхових резервів, зокрема: & 12577,6 & 14435,7 & 15828,0 & 18376,3 & 20936,7 & 22864,4 \\
\hline - резерви зі страхування життя & 3222,6 & 3845,8 & 5306,0 & 6889,3 & 7828,2 & 8389,6 \\
\hline - технічні резерви & 9355,0 & 10589,9 & 10522,0 & 11487,0 & 13108,5 & 14474,8 \\
\hline Загальні активи страховиків & 56224,7 & 66387,5 & 70261,2 & 60729,1 & 56075,6 & 57381,0 \\
\hline $\begin{array}{l}\text { Активи, визначені ст. } 31 \text { Закону України "Про страху- } \\
\text { вання" для представлення коштів страхових резервів }\end{array}$ & 48831,5 & 37914,0 & 40530,1 & 36418,8 & 35071,9 & 36084,6 \\
\hline
\end{tabular}

Складено автором на основі (Results, 2014, 2016, 2017).

Інвестиції в економіку України за напрямами, визначеними Кабінетом Міністрів України, з коштів технічних резервів i резервів зі страхування життя на 31.12.2016 р. становили 17,0 млн грн $(0,1 \%)$, на 31.12.2017 p. - 27,1 млн грн (0,1 \%) (Results, 2017).

3 метою оцінювання інвестиційної діяльності українських страхових компаній на практиці проведемо аналіз обсягів сформованих ними страхових резервів за видами впродовж 2012-2017 рр., які є основним джерелом формування інвестиційного доходу. 3 табл. 2 простежуємо динаміку страхових резервів та активів страховиків, а також темп приросту (млн грн) 2017 р. до 2012 p.

Станом на 31.12.2016 р. обсяг загальних активів страховиків становив 57381,0 млн грн, що на 2,3\% більше, порівняно з відповідним показником 2015 р. Величина активів, визначених відповідно до ст. 31 Закону України "Про страхування", збільшилась, порівняно 3 відповідним показником, станом на 31.12.2016 р. на 1 012,7 млн грн або на 2,9\% та становила 62,9 \% загальних активів страховиків (станом на 31.12.2016 р. активи, визначені за ст. 31 Закону України "Про страхування", становили 35071,9 млн грн, станом на 31.12.2017 p. - 36 084,6 млн грн) (Results, 2017). Інвестиційний потенціал складається під впливом таких чинників: структури страхового портфеля; суми страхових премій; збитковості або прибутковості пропонованих страхових операцій; умов державного регулювання щодо формування страхових фондів; термінів страхових договорів; обсягу власних коштів. Інвестиційним потенціалом визначається інвестиційна політика компанії.
Під час формування інвестиційної політики враховують чинні законодавчі норми, які регулюють інвестиційну діяльність страховиків (Закони України "Про інвестиційну діяльність", "Про страхування" та інші нормативні акти). Так, загальна вартість активів, у які інвестовані кошти, повинна дорівнювати величині власних коштів і страхових резервів страховика.

Основною метою страховика, що виступає в ролі інвестора, є забезпечення фінансової сталості для виконання зобов'язань перед страхувальниками. Зацікавленість страхового інвестора визначається досягненням цієї мети. Вітчизняні страхові компанії характеризуються низькою інвестиційною активністю, яка зумовлена різними проблемами.

До цих проблем належать недосконале нормативноправове регулювання у сфері страхування, низький рівень капіталізації вітчизняних страховиків, недостатність ліквідних фінансових інструментів для проведення ефективної політики інвестування коштів, низький рівень розвитку ринку страхування життя та інших видів особистого страхування та ін.

Активізація інвестиційної діяльності українських страхових компаній забезпечить отримання додаткових доходів та розширення сфери їхньої діяльності (Law of Ukraine, 1991). При цьому необхідно вдосконалювати законодавчу базу та ринок капіталів, щоб забезпечити ефективне функціонування страхових компаній у сфері інвестування.

Основними джерелами інвестиційної діяльності страхових компаній є власні кошти (статутний фонд, резервний фонд, прибуток, цільове фінансування і над- 
ходження) та залучені кошти (поточне надходження страхових премій, резерви страхових внесків та відшкодувань, фонд запобіжних заходів).

В умовах розвинених ринкових відносин страхова компанія зазвичай вкладає тимчасово вільні кошти в інвестиційну діяльність. Це робить рух готівкових та безготівкових коштів страховика досить складним. Такий рух охоплює два відносно самостійних грошових потоки.

Особливістю грошового обороту, пов'язаного з наданням страхового захисту, є ризиковий, ймовірний характер руху коштів. I якщо в основі формування страхового фонду лежить ймовірність збитку, то використання коштів із страхового фонду залежить від фактичних збитків страхувальника в певному році. Звідси, діяльність страховика має подвійний характер, суть якого полягає як у проведенні власне страхування, так і у виконанні ним ролі активного інвестора.

Основні функції страхових компаній, так само як i інших інституційних інвесторів, полягають в отриманні від інвестованих активів адекватної дохідності та підтримці прийнятного рівня перевищення активів над зобов'язаннями або економічного надлишку.

Водночас основними проблемами для страховиків залишається недостатність ліквідних фінансових інструментів для проведення ефективної політики інвестування коштів з огляду на призначення тимчасової адміністрації в банківських установах, у яких відкриті депозити страховиків, а також зростання ризику невиконання зобов'язань перестраховиками-резидентами.

Висновки. Розширення інвестиційної діяльності страхових компаній $є$ важливим як для економіки країни загалом, так і для конкретної страхової компанії. Ефективно організована інвестиційна діяльність певною мірою забезпечує якість страхових послуг і визначає ринкову позицію страховика, а фінансові ресурси, що акумулюються у вигляді страхових резервів, є істотним джерелом інвестицій в економіку, зокрема модернізацію виробничої інфраструктури.

Аналіз тенденцій інвестиційних вкладень страхових компаній України засвідчив, що інвестиційна діяльність демонструє недостатню реалізованість інвестиційної функції страхування, яка проявляється у структурних особливостях і дохідності інвестицій. Це зумовлено внутрішніми чинниками, до яких належать недостатність ресурсної бази, висока рентабельність страхових операцій, та зовнішніми чинниками, такими як: інфляція, нерозвиненість вітчизняного фінансового ринку, недосконалість системи державного регулювання інвестиційної діяльності страхових компаній.

Страхові компанії України ще не повністю стали інституційними інвесторами, спроможними акумулювати заощадження населення та перетворювати їх в інвестиційні ресурси. Однак, враховуючи зарубіжний досвід, можна прогнозувати значний потенціал зростання українського страхового ринку в близькій перспективі.

\section{Перелік використаних джерел}

Bazylevych, V. D. (1998). Insurance market of Ukraine: Monograph. Kyiv: Nauka Publishing House, 374 p. [In Ukrainian].

Bratiuk, V. P. (2016). Investment activity of insurance companies. Scientific Bulletin of the International Humanitarian University. Series: Economics and Management, (pp. 69-71). Odesa. Retrieved from: http://nbuv.gov.ua/UJRN/Nvmgu eim 201617 17. [In Ukrainian].

Law of Ukraine. (1991). "On Investment Activity" dated September 18, 1991. Retrieved from: http://rada.gov.ua. [In Ukrainian].

Ovcharenko, T. S. (2011). Investment strategies of insurance companies and prospects for their implementation. Bulletin of the Taras Shevchenko National University of Kyiv. Series: Economics, 121122, 33-38. Kyiv. [In Ukrainian].

Resolution. (2002). Resolution of the Cabinet of Ministers of Ukraine "On Approving the Directions of Investing in the Economy Industries at the expense of the Insurance Reserve" dated August 17, 2002, No. 1211. Retrieved from: http://zakon5.rada.gov.ua/laws/show/1211-2002-\%D0\%BF. [In Ukrainian].

Results. (2014). Results of the activity of insurance companies in 2014. Official site of the National Commission, which carries out state regulation in the field of financial services markets, $34 \mathrm{p}$. Retrieved from: https://forinsurer.com/files/file00552.pdf. [In Ukrainian].

Results. (2015). Results of the activity of insurance companies in 2015. Official site of the National Commission, which carries out state regulation in the field of financial services markets, $35 \mathrm{p}$. Retrieved from: https://forinsurer.com/files/file00565.pdf. [In Ukrainian].

Results. (2016). Results of the activity of insurance companies in 2016. Official site of the National Commission, which carries out state regulation in the field of financial services markets, $34 \mathrm{p}$. Retrieved from: https://www.nfp.gov.ua/files/sk \%202016.pdf. [In Ukrainian].

Results. (2017). Results of the activity of insurance companies in 2017. Official site of the National Commission, which carries out state regulation in the field of financial services markets, $34 \mathrm{p}$. Retrieved from: https://forinsurer.com/files/file00634.pdf. [In Ukrainian].

Sobol', R. H. (2012). The essence of state regulation of insurance activity in Ukraine. Theory and practice of public administration, 2(37), 240-245. Kharkiv. [In Ukrainian].

Sova, O. Yu. (2015). Problems and prospects of development of insurance business in Ukraine. Science and Economics, 1(37), 42-49. Khmelnytskyi. [In Ukrainian].

\section{ВЛИЯНИЕ РЕСУРСОВ СТРАХОВОГО РЫНКА В МОДЕРНИЗАЦИИ ПРОИЗВОДСТВЕННОЙ ИНФРАСТРУКТУРЫ УКРАИНСКОЙ ЭКОНОМИКИ}

Исследованы основные тенденции развития страхового рынка Украины. Охарактеризован страховой рынок как стратегически важный и перспективный сегмент экономики и источник внутренних долгосрочных инвестиций в национальную экономику, в частности - модернизацию производственной инфраструктуры. Определена сущность инвестиционной деятельности страховых компаний в сфере производственной инфраструктуры. Установлено, что страховые компании можно отнести к учреждениям, которым присуща возможность производить, прежде всего, долгосрочные инвестиционные ресурсы, дефицит которых наблюдается в украинской экономике. Прослежено рост инвестиционных рынков Украины в значительной мере за счет эффективного использования страховых ресурсов отечественных страховых компаний. Указано, что инвестиционная функция страхового рынка реализуется через размещение временно свободных средств в ценные бумаги, депозиты банков, недвижимость. Выявлены основные источники инвестиционной деятельности страховых компаний - собственные средства (уставный фонд, резервный фонд, прибыль, целевое финансирование и поступления) и привлеченные средства (текущие поступления страховых премий, резервы страховых взносов и возмещений, фонд предупредительных мероприятий). Предложены направления совершенствования государственного регулирования инвестиционной деятельности 
страховых компаний: совершенствование законодательной базы и рынка капиталов, чтобы обеспечить эффективное функционирование страховых компаний в сфере инвестирования.

Ключевые слова: производственная инфраструктура; инвестиции; страховая компания; страховой рынок.

N. M. Tsebenko

Drohobych Ivan Franko State Pedagogical University, Drohobych, Ukraine

\section{MARKET RESOURCES INSURANCE INFLUENCE ON UKRAINIAN ECONOMY INDUSTRIAL INFRASTRUCTURE MODERNIZATION}

The principal tendencies of development of the insurance market in Ukraine are investigated. The insurance market is described as a strategically important and promising segment of the economy and a source of domestic long-term investments in the national economy, in particular, the modernization of industrial infrastructure. The essence of the investment activity of insurance companies in the field of industrial infrastructure is determined. Insurance companies can be attributed to institutions which have the opportunity to produce long-term investment resources, the deficit of which is observed in the Ukrainian economy. They are able to turn temporarily free funds of individuals and legal entities into investment resources that are necessary for the development of economy. The growth of investment markets in Ukraine is traced, which is largely achieved by the effective use of insurance resources of domestic insurance companies. It is indicated that the investment function of the insurance market is implemented through the placement of temporarily free funds in securities, bank deposits, real estate, etc. The main sources of investment activity of insurance companies are identified. They consist of own capital (statutory fund, reserve fund, profit, target financing and income) and borrowed capital (current income of insurance premiums, reserves of insurance premiums and rebates, prevention fund). The Cabinet of Ministers of Ukraine included the following directions of the investment of branches of the economy at the expense of insurance reserves: development and implementation of high-tech equipment and other innovative products, development of tourism infrastructure, extraction of minerals and processing of waste from mining and metallurgical production, housing construction and development of mortgage lending market, development of transport infrastructure, development of communication and telecommunication sector. The directions of improvement of the state regulation of investment activity of insurance companies have been suggested as an improvement of the legislative base and capital market for ensuring the effective functioning of insurance companies in the field of investment.

Keywords: industrial infrastructure; investments; investment activity; own and borrowed capital; insurance company; insurance market. 